\title{
Decolonization in Herman Melville's Moby Dick
}

\author{
Hajiali Sepahvand \\ English Department, Faculty of Arts, Arak branch, Islamic Azad University, Arak, Iran \\ Email: Hajis106@gmail.com
}

\begin{abstract}
This study tries to show decolonization in Herman Melville's Moby Dick. Melville applies some narrative techniques which closely match those of the decolonization process. The narrative has a potentially representative content which opens one's horizons toward new sources of meaning and conceptual interpretation. The focal point, in this study, is to examine the decolonization level and its strategies as agency, abrogation, undermining and appropriation to see how tangibly these terms agree with the very context of the above-mentioned novel and to find out whether the purely abstract terms extracted from decolonization theory can be concretized in a practical form. Furthermore, this study aims at scrutinizing in detail the frequency and the possibility of the decolonization in the very fabric and texture of fictional narrative of the colonized nations in general.
\end{abstract}

Index Terms - abrogation, agency, appropriation, decolonization

\section{INTRODUCTION}

The process of this study starts with a brief introduction to decolonization, its strategies, and a short analysis of Herman Melville's Moby Dick, which is followed by tracing decolonization in it.

\section{DeColonization AND ITS STRATEGIES IN LITERATURE}

As a process which is the very practical advantage of post-colonial discourse, decolonization is the only way of removing the heavy burden of empire colonization which has invaded colonized countries both culturally and naturally. But to perceive decolonization as the central point of the article, first it is deserved to answer the question of what decolonization is. Then, different kinds of decolonization (Early, Present, in Settlers and invaded colonies), strategies, and colonies will be presented. Consequently, decolonization in the settler colonies will be followed by analysis of Herman Melville's Moby Dick as an example.

\section{A. Decolonization}

Weather implicit or explicit, decolonization, in general, is a revolt, against imperial domination. In other words, it is a kind of awareness against oppression and inferiority like what was done in Marxist movement against master class by slaves (working class) or by Feminist against male-centered societies. Being different in early and present involvement and engagement, like them, decolonization can be divided into two phases: first or early phase, as will be referred to in the next parts, which was started by African decolonizers derived from the works of political theorists like Frantz Fanon $(1959,1961,1967)$ and Albert Memmi (1965) who located its principal characteristic in the notion of the imperialcolonial (colonizer-colonized) dialectic itself. In this respect, The early involvement and engagement of decolonization as Ashcroft (2007) puts, is 'a profound complicity with the imperial powers from which they sought to emerge as free agents' (p.56), that is, freedom and emancipation as free subject. Fanon, writing in the 1950s during the Algerian struggle for independence from French colonial rule, through psychoanalysis of colonial subject produced the ways in which the colonial subject's identity is constructed by the colonist. In his famous and influential essay (Fanon, 1986, pp.109-40), Fanon shows the effects of racism on the construction of the subject and the production of identity. In this essay which is an interior monologue, Fanon (1986) uses the constructed identity of the oppressed narrator by the racist oppressors as:" "Dirty nigger!", "Negro!"” and eventually he puts this construction as the construction of an object among the other objects not a subject:

'I came into the world imbued with the will to find a meaning in things, my spirit filled with the desire to attain to the source of the world, and then I found I was an object in the midst of other objects. Sealed into this crushing objecthood, I turned beseechingly to others. ... .I stumbled, and the movements, the attitudes, the glances of the other fixed me there, in the sense in which a chemical solution is fixed by a dye. I was indignant; I demanded an explanation. Nothing happened. I burst apart. Now the fragments have been put together again by another self (p. 109).

On the whole, early decolonization seeks to invert the structures of domination and substituting the tradition of the colonized nations in place of imperial-dominated canon. Therefore, the early decolonization is dialectic of subject/object, self/other which is resulted in a national revolt and in Parry (1987) term 'nationalist liberationist narratives'...(p.37).

But in the present or advanced phase decolonization criticism is extended by Edward Said into the area of challenging and undermining absolute and axiomatic principles upon which the world classification into superiority of 
the occident and inferiority of the orient are established. Such classifications in Said's (1978) view are man-made, not absolute (p. 5); therefore, they are used for domination by Europe. Thus, decolonization has turned away from simple inversions towards a questioning of forms and modes, to unmasking the assumptions upon which such canonical constructions are founded in a way that it moves first to make their cryptic bases visible and then destabilizes them as Ashcroft (2007) puts it:

'decolonization is the process of revealing and dismantling colonialist power in all its forms. This includes dismantling the hidden aspects of those institutional and cultural forces that had maintained the colonialist power and that remain even after political independence is achieved. Initially, in many places in the colonized world, the process of resistance was conducted in terms or institutions appropriated from the colonizing culture itself... (P. 56-7).

\section{B. The Setter and Invaded Colonies}

Complexity of imperialist strategies and different geographical location of colonized countries is resulted in various kinds of colonization and colonies. In other words, regarding its benefits and revenues, Imperialism invades some countries, while at the same times, as Ashcroft (2004) puts, it occupies the others:

'...the settler colonies and the invaded colonies. In the case of the settler colonies like the United States, Canada, New Zealand, and Australia, land was occupied by European colonists who dispossessed and overwhelmed the Indigenous populations.... invaded societies like those in India or Nigeria, where indigenous peoples were colonized on their own territories'...(p.24).

In both cases, empire imposes its own superiority and domination through its language. This triumph is achieved through introducing English as intermediate and standard language and the writers are the subjects upon whom empire does it. Explaining this phenomenon, Maxwell (1965) demonstrates it as:

'there are two broad categories. In the first, the writer brings his own language - English - to an alien environment and a fresh set of experiences: Australia, Canada, New Zealand. In the other, the writer brings an alien language English - to his own social and cultural inheritance: India, West Africa. Yet the categories have a fundamental kinship. ... (pp. 82-3).

However, empire knows how to control and invade each nation.

\section{Decolonization in the Invaded colonies}

Regarding the cases of invaded colonies, decolonization, as was discussed in previous parts, was at first a national movement against colonization by imperialism. Therefore, it was an anti-colonialism movement which was shared by all invaded colonies. Like other movements it was changing and taking many forms so that it could get the freedom of its agents. This procedure has been presented by Ashcroft (2007) as:

'...sometimes associated with an ideology of racial liberation, as in the case of nineteenth-century West African nationalists such as Edward Wilmot Blyden and James Africanus Horton (ideologies that might be seen as the precursors of twentieth-century movements such as négritude). Conversely, it may accompany a demand for a recognition of cultural differences on a broad and diverse front, as in the Indian National Congress which sought to unite a variety of ethnic groups with different religious and racial identities in a single, national independence movement. In the second half of the twentieth century, anti-colonialism was often articulated in terms of a radical, Marxist discourse of liberation, and in constructions that sought to reconcile the internationalist and anti-élitist demands of Marxism with the nationalist sentiments of the period (National Liberation Fronts), in the work and theory of early national liberationist thinkers such as C.L.R.James, Amilcar Cabral and Frantz Fanon, ...(p. 12).

All highlighted points of this quotation as ideology of racial liberation, recognition of cultural differences, radical, Marxist discourse of liberation are different faces of freedom and emancipation from domination of Imperialism. But the radical question here is that how such emancipation is possible? In other words, how can such nations get their radical liberation while domination of Imperialism is influential everywhere and in every field, that is, culture, tradition, rutine life and social conduct? The answer is, at first, implicit in a return to pre-colonial languages. Mostly, as Ashcroft (2004) refers to, in invaded colonized as: 'African countries and in India, that is in post-colonial countries where viable alternatives to english continue to exist, an appeal for a return to writing exclusively, or mainly in the pre-colonial languages has been a recurring feature of calls for decolonization' (p.29). Another important basis of decolonization or liberation from domination of Imperialism is recognition of cultural differences which is a kind of cultural and mental decolonization. This is the consequent of the return to pre-colonial language what is in Ashcroft's (2007) view 'a return to indigenous languages can restructure attitudes to the local and the indigenous cultures....Thus, decolonizing processes that have advocated a return to indigenous language use have involved both a social programme to democratize culture and a programme of cultural recuperation and re-evaluation (p.57).

\section{Decolonization and in the Setter Colonies}

As was discussed, in the settler colonies like the United States, Canada, New Zealand, and Australia, land was occupied by European colonists who dispossessed and overwhelmed the Indigenous populations. Therefore, in these colonies, decolonization which is possible through Agency, Nationalism, Appropriation and Abrogation is different from the invaded colonies. In such colonies, according to Ashcroft (2004), 
'the first task seems to be to establish that the texts can be shown to constitute a literature separate from that of the metropolitan centre. A vast and impressive body of literary histories, thematic studies, and studies of individual literary traditions has accrued over the last one hundred and fifty years or so in the white cultures of settler colonies. The task of compiling a national literary history has usually been an important element in the establishment of an independent cultural identity' (p.131).

This decolonization which was the concern of early decolonizers can be seen in H.M. Green(1961); Carl F. Klinck (1965), a large body of text in the United State (Russell Reising, 1978), and many others. Thus, the early stage of decolonization is a kind of consciousness through which settler colonized people perceive themselves as individuals who can freely and autonomously initiate action and construct their own identity, that is, Agency, which in Ashcroft's (2007) view

'refers to the ability to act or perform an action. In contemporary theory, it hinges on the question of whether individuals can freely and autonomously initiate action, or whether the things they do are in some sense determined by the ways in which their identity has been constructed. Agency is particularly important in post-colonial theory because it refers to the ability of post-colonial subjects to initiate action in engaging or resisting imperial power' (p.6).

In the later stages some decolonizers try to develop their self- assertion through independent national literature in a controversial way as in L. Kramer (1981), W.H. New (1989), and Charles Brockden Brown (1799) in America. But, the problem to which they meet is lake of a national and local language as their own language. In other words, the language through which they want to establish and express a separated independent national cultural identity is metropolitan language:

'The colonial writer does not have words of his own....Try to speak the words of your home and you will discover if you are a colonial - that you do not know them . . . perhaps our job was not to fake a space of our own and write it up, but rather to find words for our space-lessness ... Instead of pushing against the grain of an external, uncharged language, perhaps we should finally come to writing with that grain' (Lee 1974, pp.162,163).

Therefore, the real concern is the control over the means of communication, that is, power of writing in the colonial situation as has been discussed in The Conquest of America by Tzvetan Todorov (1974). But how is it possible while the only dominant language as the medium of power is the language of the centre? In other words, post-colonial writing only can defines itself by seizing the language of the centre: 'The crucial function of language as a medium of power demands that post-colonial writing defines itself by seizing the language of the centre and re-placing it in a discourse fully adapted to the colonized place'(Ashcroft, 2002, p.37). It is because language is the medium through which a hierarchical structure of power is perpetuated, and conceptions of truth, order, and reality become established. Postcolonial writing is going to reject such power and; therefore, post-colonial writing is the process by which the language, with its power, and the writing, with its signification of authority, has been seized from the dominant European culture. Post-colonial writing does this through two process of

"the abrogation or denial of the privilege of 'English' involves a rejection of the metropolitan power over the means of communication" and "the appropriation and reconstitution of the language of the centre, the process of capturing and remoulding the language to new usages, marks a separation from the site of colonial privilege. Abrogation is a refusal of the categories of the imperial culture, its aesthetic, its illusory standard of normative or 'correct' usage, and its assumption of a traditional and fixed meaning 'inscribed' in the words. It is a vital moment in the de-colonizing of the language and the writing of 'english', but without the process of appropriation the moment of abrogation may not extend beyond a reversal of the assumptions of privilege, the 'normal', and correct inscription, all of which can be simply taken over and maintained by the new usage (Ashcroft et al., 2004, p. 37).

Therefore, post-colonial text is itself a site of struggle for linguistic control which is resulted in the appropriating discourse. This struggle extends to the disputes concerning theme, form, genre definition, implicit systems of manner, custom, and value.

Now, the question is that may we say that language constitutes reality? Paradoxically, it should be said that yes! But where is the center of reality, that is, its axiomatic center according which the other realities by other languages are constructed? The answer is that there is not any centre of reality just as there is not any pre-given unmediated reality and control over the means of communication determines the center of reality; therefore, the colonized nations through appropriation of language of metropolitan centre-- 'to convey in a language that is not one's own the spirit that is one's own' (Rao, 1938, p.vii), or makes it 'bear the burden' of one's own cultural experience (Achebe, 1975, p. 62)-- and selfassertion abrogate its centrality and they define themselves as the centre and they may reconstruct reality according to their own pattern of conventions, expectations, and experiences, that is, establishment of the link between the received English and place or in Emerson's phrase, , their 'original relation with the universe' (Emerson, 1836,p.21).

In a sense, eventually, abrogation through appropriation, which was operated by some decolonizers, is a kind of deconstruction. Because, they use language in a way which disrupts its binary strurcturation. This pattern of binary structuration in European and many other languages, for such critics among whom Wilson Harris (1985) is well known, lies at the root of the continual pattern of conquest and domination that has formed the structure of human history; therefore, tracing aporia in such a pattern is possible.

\section{DeCOlONIZATION IN MOBY DiCK}




\section{A. Ishmael as American Adam and American Agency}

Among different themes of American literature, the theme which is the very projection of the archetypal tendency of the myth of Edenic dream or Dream land which is as old as the man's mind, is the notion of the American Adam, the mythic New World hero who is the very representative of independent American national identity, that is, American decolonization. In The American Adam, R. W. B. Lewis describes the type as:

"a radically new personality, the hero of the new adventure: an individual emancipated from history, happily bereft of ancestry, untouched and undefiled by the usual inheritances of family and race; an individual standing alone, self-reliant and self propelling, ready to confront whatever awaited him with the aid of his own unique and inherent resources" (p.5).

The above mentioned particular characteristics have been embodied in Ishmael whom Melville intentionally introduces in order to announce the very independent national American character, unlike early literary characters who are the followers and copy of European characters, who is self-reliant and achieves and proves his own American identity through some great deeds so that he could challenge European superiority and American inferiority which is because of their dependent identity. Ishmael announces his self-reliance and confirms his independent ways by telling us that he seeks no special rank aboard ship and would not want to be either a cook or a captain; he says he has enough responsibility just taking care of himself:

I never go as a passenger; nor, though I am something of a salt, do I ever go to sea as a Commodore, or a Captain, or a Cook. I abandon the glory and distinction of such offices to those who like them. For my part, I abominate all honorable respectable toils, trials, and tribulations of every kind whatsoever. It is quite as much as I can do to take care of myself, without taking care of ships, barques, brigs, schooners, and what not. (Ch. 1, p.3).

Moreover, Ishmael's bereft of ancestry is centralized in the very beginning of the novel when Melville employs biblical allusions as keys to clarify this notion. The biblical Ishmael (Genesis 16:1-16; 21:10 ff.) is disinherited and dismissed from his home in favor of his half-brother Isaac. The name suggests that the narrator is something of an outcast, a drifter, a fellow of no particular family other than mankind, that is, American Adam who 'untouched and undefiled by the usual inheritances of family and race', because we are not informed through the novel about his family. In other words, neither Ishmael nor Melville speaks of a family or even a last name for Ishmael. This is confirmed with the ending of the book in which only Ishmael survives, picked up by the whaling ship Rachel, which, searching his own missing children, finds only "another orphan" (Epilogue, p. 460), that is, American Adam who, unlike European's, untouched and undefiled by the usual inheritances of family and race'. Ishmael as 'a radically new personality, the hero of the new adventure', another feature of American Adam, is the real quest in the search of truth because he is an openminded character who is capable of change and growth. This change and spiritual growth, first, occurs when he links his questing and heroism to the great ancient myths as:

....as every one knows, meditation and water are wedded for ever.... Why did the poor poet of Tennessee, upon suddenly receiving two handfuls of silver, deliberate whether to buy him a coat, which he sadly needed, or invest his money in a pedestrian trip to Rockaway Beach? Why is almost every robust healthy boy with a robust healthy soul in him, at some time or other crazy to go to sea? [consciously experience of Archetypal tendency of heroism, that is, Mythology] Why upon your first voyage as a passenger, did you yourself feel such a mystical vibration, when first told that you and your ship were now out of sight of land? Why did the old Persians hold the sea holy? Why did the Greeks give it a separate deity, and own brother of Jove? Surely all this is not without meaning. And still deeper the meaning of that story of Narcissus, who because he could not grasp the tormenting, mild image he saw in the fountain, plunged into it and was drowned. But that same image, we ourselves see in all rivers and oceans. It is the image of the ungraspable phantom of life; and this is the key to it all. ... fifty years ago did Nathan Swain (Mythical Biblical name) kill fifteen whales between a sunrise and a sunset (p.2-3).

Reasoning his archetypal tendency through linking it to the Mythology of the civilized nations as old Persians and Greeks... to justify his initiation and metaphysical investigation as a model of American hero or aspiring mind of Chistopher Marlow's Dr. Faust, Ishmael is Melveil's establishment and introducing the American Archetype of Heroism. In other words, Melveil is going to depict American Myth through heroism exactly like Ferdosie's Rostam who was fighting with a Serpant or Giant or Humer, Virgil, Spenser...; thus, Moby Dick is the Myth of America. In other words, he tries to undermine the very axiomaticly dominant European Character through showing independently American practically archetypal tendency in parallel to the other nations as well as his open mind as superior to Europe.

Correspondingly, Ishmael justifies his questing and heroism through advocating the role and importance of the whaleman in the history and he, for example, alludes to Alfred the Great (849-99 A.D, king of Wessex 871-99) who ended the Danish conquests in England and promoted English culture:

'It was the whaleman who first broke through the jealous policy of the Spanish crown, touching those colonies; and, if space permitted, it might be distinctly shown how from those whalemen at last eventuated the liberation of Peru, Chili, and Bolivia from the yoke of Old Spain, and the establishment of the eternal democracy in those parts. That great America on the other side of the sphere, Australia, was given to the enlightened world by the whaleman'....'the whale no famous author, and whaling no famous chronicler? Who wrote the first account of our Leviathan? Who but mighty Job! And who composed the first narrative of a whaling-voyage? Who, but no less a prince than Alfred the Great, who, 
with his own royal pen, took down the words from Other, the Norwegian whale-hunter of those times! And who pronounced our glowing eulogy in Parliament? Who, but Edmund Burke' (Ch. XXII, p.86).

Finally for Ishmael, however, there is a significant pride in being a whaling seaman. He wants his readers to be aware that great men such as Hercules, Jonah, and even the Hindu god Vishnu are associated with whales; in addition, he is fairly certain that St. George himself actually fought a whale rather than a dragon ( Ch. LXXVI, pp. 291-2-3).

Another change and spiritual growth of Ishmael occurs when he first meets Queequeg, in a bed they share at the Spouter-Inn. He sees the South Seas islander as a stereotypical "heathen" and fears that he is about to be killed by a cannibal. Just the opposite is true. Ishmael soon learns that Queequeg is one of the finest men whom he has ever known - caring, kind, generous, loyal, courageous, and wise. The discovery of Queequeg by Ishmael is resulted in some universal truths which are the signs of Initiation of Americanhood or very agency which is indirectly abrogating European selfishness and superiority to the other nations. In their first morning confrontation, Ishmael concludes that

'Queequeg, under the circumstances, this is a very civilized overture; but, the truth is, these savages have an innate sense of delicacy, say what you will; it is marvelous how essentially polite they are. I pay this particular compliment to Queequeg, because he treated me with so much civility and consideration, while I was guilty of great rudeness; ... Nevertheless, a man like Queequeg you don't see every day, he and his ways were well worth unusual regarding. But Queequeg, do you see, was a creature in the transition state - neither caterpillar nor butterfly. He was just enough civilized to show off his outlandishness in the strangest possible manner (Ch.3, p.22).

Under Queequeg's influence, Ishmael is opening his mind to the nature of mankind and the values to be found, that is, initiation of Americanhood or agency. Moreover, Ishmael walks about New Bedford, the port city, which offers him more opportunities to observe people from other cultures: sailors from around the world, country dwellers, even real cannibals (Ch. 6, p.26). He is beginning to enjoy the diversity of this world; therefore, he depicts the initiation of Americanhood whom Melveil is purposely introduces as the high capacity and melting pot in which all people are regarded as well as discovering the positive aspects of them to establish cross-culturality.

As 'the hero of the new adventure', Ishmael goes to the Whaleman's Chapel where he notices numerous memorial tablets honoring men who died at sea (Ch.7, p. 26). Ishmael thinks about death and immortality. At the chapel, Ishmael's thoughts turn to death and the question of what is important about life-what, if anything, survives after death (p. 27). Because this little church primarily serves whalers, it prominently displays a number of memorial tablets honoring men killed at sea. Ishmael considers his own mortality and wonders if he will meet the fate of these men. His spirits rise, however, when he concludes that his physical self is not the real Ishmael at all. It is a shadow; and his shadow, his spirit, is his true substance [a really spiritual quester]. He concludes that we humans are like oysters at the bottom of the sea, limited in our view of reality. We are confused about what is important (p. 28). In that frame of mind, he awaits the sermon and it is initiation of opening his mind.

\section{B. White Whale as Melville's (American) Autotype Archetype}

Melville produced a great novel, but the plot of Moby Dick was not his invention. It was a well-known mythic narrative long before he immortalized it as tragic novel. 'Moby Dick, the strange, fierce white whale that Captain Ahab pursues with such relentless fury, was already a legend among the whalers, who knew him as "Mocha Dick"(Reynolds, 1839).' Melville rebuilt it by adding a poetic or moral significance to it. Both the myth and the novel contain a number of familiar archetypes.

James Baird in Ishmael: a Study of the Symxpebolic Mode in Primitivism tries 'to find an archetypal key to the multilayered meanings of Moby Dick....He finds this key in primitive mythology, especially in the myths of Polynesia to which young Melville had been exposed during his two years of sea duty in south Pacific (...cannibals of Taipi) (Guerin, 1999, p. 185).

Thus he purposely tries to establish the very prototype or American original Archetypes which are the elements of national cultural identity and declaration of national cultural identity, that is, decolonization or abrogation of European cultural domination. He does it through fusion of archetype and autotype; therefore, his literary primitivism is authentic because, as "says Baird, he had absorbed certain Asian archetypes or "life symbols" and then transformed theses creativity into “autotypes”(that is, individualized personal symbols)' (Guerin, 1999, p. 185). In other words, Melveil establishes American independent archetype to achieve its own identity.

Moby Dick as the creative fusion of archetype and autotype by Melville is elaborately combination of Asian archetypes of great fish or whale and whiteness, as his own creative unique symbol (autotype), as Baird put it:

throughout Asian mythology, the "great fish" ... as symbol of divine creation and life; in Hinduism,..., the whale is an avatar(divine incarnation) of Vishnu, the "the preserver contained in all being of Brahama.... Whiteness is the archetype of the all encompassing, inscrutable deity, the "white sign of the God of all being who has borne such Oriental names as Bhagavat, Brahama- the God of endless contradiction.” (Guerin, 1999, p.185).

To perceive the very archetypal or 'universal symbolic'(Guerin, 1999, p. 160) notion of the whiteness, Ishmael refers to its general meanings as purity, mystery, and terror among different nations. In the case of purity, he refers to

beauty, as in marbles, japonicas, and pearls; and even the barbaric, grand old kings of Pegu placing the title "Lord of the White Elephants" the modern kings of Siam unfurling the same snow-white quadruped in the royal standard great Austrian Empire, Caesarian, heir to overlording Rome, having for the imperial color the same imperial hue; significant of gladness, for among the Romans a white stone marked a joyful day; , noble things - the innocence of brides, the 
benignity of age; among the Red Men of America the giving of the white belt of wampum,was the deepest pledge of honor; though in many climes, whiteness typifies the majesty of Justice in the ermine of the Judge even in the higher mysteries of the most august religions it has been made the symbol of the divine spotlessness and power; by the Persian fire worshippers, the white forked flame being held the holiest on the altar; and in the Greek mythologies, Great Jove himself made incarnate in a snow-white bull...( Ch. XL, pp.154-60)

In short, in that whiteness, Ishmael sees innocence and evil, glory and damnation; therefore, Melville introduces American archetype of white whale or Moby Dick which falls, based on different interpretations, in the scope of Ishmael's purity, mystery, and terror. To Starbuck, Moby Dick is just another whale, except that he is more dangerous (terror). In Chapter 34, Starbuck calls it "blasphemous" to seek revenge on a "dumb brute . . . that simply smote thee from blindest instinct!" If Starbuck sees anything beyond that in the whale, it is that Moby Dick represents the captain's madness and a very serious diversion from the ship's proper mission. To Ahab, "There would be great glory in killing him, I know that; and? Ishmael grants that Ahab views the whale as an embodiment of evil, that is, Jungian shadow or Ahab's failure of individuation. In chapter 34, there, the captain says he sees Moby Dick as a "mask," behind which lies a great power whose dominance To Ahab, we might conclude, the White Whale represents that power which limits and controls man in the novel(p. 131). On the whole, Melveil tries to undermine and abrogate European domination and he announces mythological part of American identity and culture, that is, decolonization.

\section{CONCLUSION}

In this study, a number of decolonization techniques were applied to Melville's Moby Dick respectively to see how decolonization can be accounted for in terms of literary development.

In Moby Dick, the decolonization as proposed by Said and recently by Ashcroft, was strategically and essentially used. The important point is that the novel is metaphorically replete with independently announcement of American literary identity from Europe as in the preface to his novel, Charles Brockden Brown (1799) announces that the field of investigation, opened to us by our own country, should differ essentially from those which exist in Europe (p.29). Therefore, decolonization at least can be applied to this early American novel.

Ishmael's heroism as mythic American Adam is purposely challenge of European axiomatically superiority in the novel by Melville in a way that thoughtful readers will notice its significance as soon as they start reading the novel. In this heroism temerity, boldness, and impetuosity of American and the Americanhood has been depicted.

To actualize abrogation of the absolutely centrality of Europe, we traced the very mastery of Melville in creativity of independently American autotypes in the masterly spiritual and physical heroism and the high capacity of Ishmael as the embodiment of melting pot in the novel.

The important point is that this American character, different from European's, is raised and matured as a selfreliance character. This genius task is the rite of initiation of self-reliant American character as the archetypal model for American characters whom Melville differentiates from European Character, that is, abrogating and undermining European literature and characters as the universal superior literature and characters or declaration of independence of America through literature.

\section{REFERENCES}

[1] Achebe, Chinua. (1975.) Morning Yet on Creation Day. New York: Doubleday.

[2] Ashcroft, W.D et all. (2004). The Empire Writes Back. London: Routledgep.

[3] Ashcroft, W.D et al. (2007). Post-colonial Studies, The Key Concepts, Routledge, Taylor \& Francis e-Library.

[4] Brockden Brown, Charles. (1973). Edgar Huntly. Ed. David Stineback. New Haven: College and University Press.

[5] Emerson, Ralph, Waldo. (1836). 'Nature' in Stephen E. Whicher (ed.). Selections from Ralph Waldo Emerson. Boston, MS: Houghton Mifflin 1956.

[6] Fanon, Frantz. (1959). Studies in a Dying Colonialism. Trans. H. Chevalier. Harmondsworth: Penguin, 1970.

[7] Fanon, Frantz. (1961). The Wretched of the Earth. Harmondsworth: Penguin.

[8] Fanon, Frantz. (1967). Black Skin. White Masks. New York: Grove Press.

[9] Fiedler, Leslie. (1960). Love and Death in the American Novel. New York: Dell.

[10] Fussell, Edwin. (1965). Frontier: American Literature and the American West. Princeton: Princeton UP.

[11] Fender, Stephen. (1992). Sea Changes: British Emigration \& American Literature. Cambridge: Cambridge UP.

[12] Fanon, Frantz. (1986). Black Skin, White Masks, trans. Charles Lam Markmann, London: Pluto Press.

[13] Fanon, Frantz. (1952). Black Skin White Masks (trans. Charles Lam Markmann). London: Paladin [1968].

[14] Green, H.M. (1961). A History of Australian Literature, 2 vols., Sydney: Angus and Robertson.

[15] Guerin, Wilfred L. (2005). A Hand Book of Critical Approaches to Literature. Oxford University Press.

[16] Harris, Wilson. (1985). Harris. 'Adversarial contexts and creativity', New Left Review, 154 (Nov.-Dec.).

[17] Jung, C. G (1968). Man and his Symbols, London: Adus.

[18] Klinck, Carl F. (1965). Literary History of Canada: Canadian Literature in English, 3 vols, Toronto/London: University of Toronto Press.

[19] Kramer, L. (ed.) (1981). The Oxford History of Australian Literature. Melbourne: Oxford University Press.

[20] Lee, Dennis. (1974) 'Cadence, country, silence: writing in colonial space', Boundary 2,3, 1 (Fall).

[21] Lewis, R. W.B. (1908). The American Adam. Chicago: University of Chicago Press.

[22] Maxwell, D.E.S. (1965). 'Landscape and Theme' in Press 1965. 
[23] Melville Herman. (1936). Moby Dick or the White Whale, Spenser press.

[24] Memmi, Albert. (1965). The Colonizer and the Colonized (trans. HowardGreenfield). Boston, MA: Beacon Press

[25] Memmi, Albert. (1965). The Coloniser and the Colonised. New York: Orion Press.

[26] New, W.H. (1989). A History of Canadian Literature. London: Macmillan.

[27] Parry, Benita. (1987). 'Problems in current theories of colonial discourse', Oxford Literary Review.

[28] Reynolds, J. N. (1839). Mocha Dick, Knickerbocker Magazine, May.

[29] Rao, Raja. (1938). Kanthapura. New York: New Directions.

[30] Reising, Russell. (1987). The Unusable Past: Theory and the Study of American Literature. New York and London: Methuen (New Accents).

[31] Roderick, Colin (ed.) (1972). Henry Lawson: Short Stories and Sketches 1888-1922. Vol. 1 of Collected Prose. Sydney: Angus and Robertson.

[32] Roosenberg Donna. (1986). World Mythology, NTC Publishing Group, Lincolnwood, Illinois USA.

[33] Said, Edward. (1978). Orientalism. New York: Pantheon.

[34] Stow, Randolph. (1979). Visitants. London: Picador.

[35] Todorov, Tzvetan. (1974). The Conquest of America: The Question of the Other. Trans. Richard Howard. New York: Harper and Row 1982.

[36] Tutuola, Amos. (1952). The Palm-Wine Drinkard. London: Faber \& Faber.

Hajiali Sepahvand is an instructor at Payame Nor University, Khoram Abad, Iran. His main areas of research are Criticism, Novel and drama. He holds a B. A. and M.A in English Language and Literature and he is pursuing his studies in PhD level at National Academy of Sciences in Armenia. 